\section{Ko e Ako ‘a e Kakai Pasifika, Pacific Islands Peoples' Education in Aotearoa, New Zealand Towards the 21st Century}

\author{
LESIELI TONGATI'O
}

\section{Abstract:}

In December 1996, the Secretary for Education, Howard Fancy launched Ko e Ako 'a e Kakai Pasifika, ${ }^{1}$ the Ministry of Education's plan for raising the quality of education for Pacific Islands ${ }^{2}$ peoples in New Zealand. The plan is a first step towards developing a long-term Pacific Islands education strategy. It has been 16 months since the plan was launched and it is encouraging to see the variety of initiatives being implemented to achieve its goals. This paper will discuss these initiatives more fully.

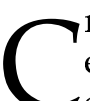

reating opportunities for Pacific peoples' success in New Zealand education poses immense challenges for all educators. ${ }^{3}$ These challenges are even greater when the educational system is trying to improve educational outcomes for a population within a system that is largely devolved to self-managing schools, a management system that is vastly different from the centrally-driven educational systems prevalent in many Pacific home countries. For Pacific peoples, education is highly valued both generally, and as a vehicle for development and social mobility. Many Pacific countries have achieved well and claim long education histories, some having schools established for well over 100 years.

It is well-known that Pacific peoples migrated to New Zealand in search of better economic and education opportunities. The New Zealand Pacific population is fast-growing and young, now making up
134 Lesieli Tongati'o

just over 6 percent (1996) of the total population, and expected to double to about 12 percent by the year 2051. More significantly, over 63 percent of the Pacific population is concentrated in the Auckland area, with another 17 percent in the Wellington area and the rest scattered in other urban centres and smaller towns. There is an increasing number of New Zealand-born Pacific children (Krishnan et al., 1994). Students of Pacific origin currently constitute 7 percent of the school population, estimated to rise to 11 percent by the year 2031. Just under 50 percent of the Pacific population are under 20 years of age, so a large proportion continues to be involved in compulsory and post-compulsory education (Ministry of Education, 1996).

Yet when Pacific peoples migrate to New Zealand, a large number experience low educational achievement, despite having high educational aspirations. However, there is now an emerging group of well-educated, articulate and forward-looking Pacific peoples, both born in Pacific countries and in New Zealand, who, while still very much in the minority, are becoming effective role models for young Pacific people. Successful Pacific peoples are perceived as those who have achieved academic success while at the same time maintaining a strong Pacific/New Zealand cultural identity. They are able to bridge and value important structures and expectations of their first generation Pacific migrant parents and the emerging culture and expectations of New Zealand-born Pacific peoples.

There is still a long way to go. But education stakeholders are continuing to find innovative ways to ensure Pacific peoples meet their educational aspirations, and have increasingly recognised that Pacific cultural heritages can add value to an academic education. These challenges, and the fact that Pacific communities must be partners in identifying, developing and managing solutions, need to be addressed if strategies are to be successful. Education for Pacific peoples must be viewed as a holistic enterprise. All concerned must take responsibility for successful learning, have clearly defined roles and responsibilities, and provide support networks for students, teachers and parents.

Background Factors Contributing to Low Education Achievement

A variety of factors have contributed to Pacific students' low educational achievement over the years. These factors have included contextual, systemic, and structural difficulties faced by Pacific communities both within schools and within the broader community. Discussions on low achievement have traditionally been based on the results of the senior 
secondary school examinations, but it is also important when discussing achievement (particularly performance on senior school examinations) to consider it in the light of the broader social and economic realities within which Pacific peoples in New Zealand live.

The table below highlights some of the factors that affect Pacific peoples' performance in education (see Tongati'o, 1994).

\begin{tabular}{|c|c|c|c|}
\hline $\begin{array}{c}\text { Contextual } \\
\text { Factors }\end{array}$ & $\begin{array}{l}\text { Systemic } \\
\text { Factors }\end{array}$ & $\begin{array}{c}\text { Structural } \\
\text { Factors }\end{array}$ & $\begin{array}{l}\text { School } \\
\text { Factors }\end{array}$ \\
\hline $\begin{array}{l}\text { poverty and } \\
\text { various } \\
\text { impairments } \\
\text { overcrowding } \\
\text { unemployment } \\
\text { welfare } \\
\text { dependency } \\
\text { health problems } \\
\text { language } \\
\text { cultural } \\
\text { differences } \\
\text { immigrant } \\
\text { population } \\
\text { cultural practices } \\
\text { different value } \\
\text { systems } \\
\text { authoritarian } \\
\text { structures }\end{array}$ & $\begin{array}{l}\text { regulations and } \\
\text { legislation } \\
\text { resourcing } \\
\text { lack of specific } \\
\text { education policies } \\
\text { for Pacific peoples } \\
\text { lack of clarity in } \\
\text { the provision of } \\
\text { information to } \\
\text { Pacific } \\
\text { communities } \\
\text { monocultural } \\
\text { systems } \\
\text { different } \\
\text { communication } \\
\text { systems }\end{array}$ & $\begin{array}{l}\text { understanding the } \\
\text { different types of } \\
\text { schooling } \\
\text { available } \\
\text { school } \\
\text { organisation and } \\
\text { management } \\
\text { devolution } \\
\text { centralisation } \\
\text { parent } \\
\text { involvement } \\
\text { with schools } \\
\text { access } \\
\text { differences } \\
\text { between home } \\
\text { and school } \\
\text { structures and the } \\
\text { trust parents place } \\
\text { on schools }\end{array}$ & $\begin{array}{l}\text { BoTs and school } \\
\text { governance } \\
\text { principals } \\
\text { and senior } \\
\text { management } \\
\text { teacher quality } \\
\text { student support } \\
\text { school, parent and } \\
\text { community } \\
\text { relationships } \\
\text { learning and } \\
\text { teaching styles } \\
\text { school culture and } \\
\text { processes } \\
\text { career planning } \\
\text { assessment and } \\
\text { evaluation } \\
\text { processes } \\
\text { communications } \\
\text { expectations }\end{array}$ \\
\hline
\end{tabular}

A variety of Ministry of Education projects ${ }^{4}$ have identified similar factors and have contributed to the discussion and the development of initiatives for Pacific education. This is the background against which $K_{0}$ e Ako 'a e Kakai Pasifika has been developed. It is the Ministry of Education's plan for Pacific Islands education, with initiatives from early childhood through to tertiary education.
This paper outlines the plan, and analyses the processes of its development and implementation. Ko e Ako 'a e Kakai Pasifika is a document bringing together information and policy programmes designed to assist Pacific peoples to increase their participation and achievement in all areas of education.

\section{The Development of Ko e Ako 'a e Kakai Pasifika}

In December 1996, the Secretary for Education, Howard Fancy, launched Ko e Ako 'a e Kakai Pasifika. In the foreword to the document, he acknowledged that "Pacific peoples are an integral part of New Zealand's total population and school population." It is important that "Pacific peoples are able to fully participate in the New Zealand education system", and that they should be "able to acquire a high level of skills and qualifications from that education" (Ministry of Education, 1996).

The plan was developed over a period of two and a half years in consultation with Pacific education stakeholders. Initial consultation fono ${ }^{5}$ were held with Pacific educators, parents, senior secondary and tertiary students, principals and teachers of Pacific students. Information gathered from these fono was analysed and documented. Alongside consultation fono, a literature review of research about Pacific education and relevant education policy documents was conducted. This provided a summary of Pacific education issues, and noted that some issues have been documented as being of concern for several years.

The information gathered was reported in a document entitled Challenging Success, Developing Pacific Islands Education in Aotearoa, New Zealand. This was the first document to provide an overview of Pacific education in New Zealand. It recommended that the Ministry of Education develop a strategic plan for Pacific Islands education, in which policy and implementation initiatives would be developed and coordinated to meet the education needs of the Pacific students.

Ko e Ako 'a e Kakai Pasifika has built on the earlier document, and was taken out for further consultation with Pacific education stakeholders seeking ownership, agreement and commitment to its goals. The final document acknowledges the unreserved agreement given by those consulted and the Ministry's commitment to its implementation. Providing feedback to Pacific communities will continue to be important. 
An external Pacific Islands Education Advisory Group was established by the Ministry to assist with the second round of consultations and further development of goals and key objectives. Advisory Group members were nominated from the six largest Pacific communities across the country. Alongside the Advisory Group, an internal Ministry Overview Group was also established to help develop the plan.

Alongside community consultations were internal Ministry of Education consultations with Senior Managers and the Strategic Management Group, determining the most appropriate divisions to be responsible for meeting specific goals in the plan. The internal consultation enabled divisions to assist in the process by ensuring that the goals were clear, the targets achievable and drew upon the strengths of other Ministry projects, and that responsibility for delivery was spread across the Ministry.

The plan is a living document which will grow and change with the changing education needs of Pacific peoples, a first step towards developing strategic directions for Pacific Islands education. It will respond to Government initiatives and key results established by the Ministry of Education. Monitoring of the plan's implementation will be a key activity and will help in identifying gaps and areas that need further development.

Parts of the introduction to Ko e Ako 'a e Kakai Pasifika are presented in the form of questions and answers, and are summarised in the following section.

\section{What is Ko e Ako 'a e Kakai Pasifika?}

Ko e Ako 'a e Kakai Pasifika is the Ministry of Education's plan for raising the quality of education for Pacific peoples in New Zealand. This plan will help Pacific peoples gain full participation and achievement in all areas of education. The Pacific population is young and diverse in culture and language. How this population experiences education depends on its holistic well-being in spiritual, intellectual and physical growth. Fanau, parents, communities, and schools can work together towards helping Pacific students succeed within the learning community. This plan is based on the principles of empowerment, of recognising, resourcing, and building on "kakai Pasifika" strengths. Through success in education, Pacific peoples can realise their full potential and contribute even more positively to New Zealand society.

\section{What are the Plan's Main Goals?}

The plan's main goals are to facilitate high-quality Pacific Islands early childhood services, effective school programmes, and increased participation and success in tertiary education. A good beginning in early childhood education will help foster student achievement within schools. School success will enable more Pacific Islands school leavers to enrol and succeed in post-secondary education and training, and in higher tertiary-level education. The plan also identifies other goals that apply across education levels, such as bilingual education. These goals are listed in more detail later in this article.

\section{How will the Plan Respond to Change?}

Ko e Ako 'a e Kakai Pasifika will continue to evolve as objectives are met and education priorities for Pacific peoples change. The results of the plan's projects and initiatives will be monitored and evaluated regularly. This will ensure that it is appropriate and responsive to the changing needs of Pacific Islands children, students, educators, and families, and that it contributes to increasing participation and achievement. Ongoing analysis will identify any differences between the needs of Pacific migrants and first, second, and subsequent generations born in New Zealand. This early identification of potential problems will give the Ministry an advantage in developing policy and proposing appropriate delivery options for Pacific students. Providing policy developers, teachers, and other mainstream providers with skills to cater more effectively for Pacific students will be crucial for carrying out the plan successfully.

\section{How will the Plan Contribute to Relevant Government Strategic} Result Areas?

The Government's Strategic Result Areas set out the contribution that the Ministry of Education is required to make to achieve the Government's strategic vision for education. Ko e Ako 'a e Kakai Pasifika will help the Ministry achieve the Government's strategic vision for education. These strategic result areas may change from time to time, but in the 1996/97 year the plan was designed to contribute towards Pacific peoples' being able to:

- increase participation in early childhood care and education;

- $\quad$ succeed within the New Zealand education system; 
- gain recognised qualifications in the tertiary sector;

- develop higher and more appropriate skills that enable them to gain employment in a variety of areas, including those that produce high income;

- improve, by closer involvement with government agencies and schools, their long-term prospects of building supportive, confident families experiencing success in education;

- help Pacific peoples enhance their standard of living in New Zealand.

\section{How will the Plan Contribute to Relevant Ministry Key Result Areas?}

The Key Result Areas of the Ministry of Education for 1996/97 contributed to the Government's Strategic Result Areas. In turn, Ko e Ako 'a e Kakai Pasifika's goals, objectives and initiatives contributed towards achieving the Ministry Key Results in that year, and may change from year to year, reflecting the Government's strategic vision for education.

In the 1996/97 year the plan contributed towards achieving the Ministry's Key Results in research, curriculum development, learning resource development, support for Pacific board of trustees members, ongoing professional development for Pacific teachers and improving school/parent/community liaison in schools with high Pacific rolls.

In the 1997/98 year, Ko e Ako 'a e Kakai Pasifika will contribute to the Ministry's work towards developing policies and strategies that are responsive to individuals and groups with diverse and special needs, and those at risk of poor educational outcomes. This will enhance the quality of the education available to New Zealand students at all levels of the education system. Policies under this heading are concerned to ensure that the quality of education available to New Zealand students continues to increase. These initiatives will include further development in Pacific early childhood education and other sectors, which will increase participation and improve the overall quality of the learning environment.

\section{The Goals of Ko e Ako 'a e Kakai Pasifika}

\section{Early Childhood Education}

The plan's goals for Pacific early childhood education are to:

1. Increase the number of Pacific Islands children enrolled in early childhood services, and the number of licensed and chartered Pacific Islands early childhood centres (PIECCs).
2. Identify initiatives and propose a long-term Pacific Islands early childhood education-development plan, promoting quality, child health and welfare, ongoing support for early childhood centres, staff training, and the resourcing and strengthening of curriculum and management practices.

Context

Unique to early childhood education in New Zealand has been the development of Pacific early childhood centres. Pacific centres provide early childhood education through learning and maintaining Pacific languages, cultural and spiritual values. Centres provide at least 50 percent of their programme in a Pacific language. They range from informal play groups meeting for one or two sessions a week, to licensed and chartered all-day services.

The first groups started in 1986. By 1987, 14 groups were established. By July 1997, the number of funded Early Childhood Development Unit (ECDU) Pacific Islands Language Groups (PILGs) had expanded to 150, and a further 34 were licensed and chartered. The number of unlicensed PILGs continues to grow unabated.

Enrolments in Pacific services increased by 15 percent between 1992 and 1997, last year catering for 4,348 children. Pacific parents are clearly showing a preference for enrolling their children in Pacific centres, with 43 percent (1997) of Pacific Islands children who were enrolled in an early childhood service attending a Pacific centre. The next highest preferred service is kindergarten, with 31 percent of Pacific enrolment. However, collectively just under 57 percent of Pacific Islands children are enrolled in mainstream services.

Progress

In order to achieve the above goals, the Ministry has implemented the following projects:

a) The Ministry has Purchase Agreements with the Pacific Islands Early Childhood Council Aotearoa (PIECCA), Kautaha Aoga Niue (KAN) and the Early Childhood Development Unit (ECDU) to provide pre- and post-licensing support to developing groups.

b) The Early Childhood Discretionary Grants Scheme Pacific Islands Pool was established in 1996, and provides funding for Pacific centres to upgrade premises or build new centres to meet licensing requirements. The pool has funding of $\$ 1.0$ million to allocate each 
year and applications are sought from Pacific centres. To date, 18 centres have received grants from this pool.

c) The Targeted Assistance Project provides extra assistance to centres. A purchase agreement with PIECCA has been finalised to provide pre- and post-licensing support to groups.

d) The Ministry has a purchase agreement with the ECDU to provide Professional Development Programmes to a specified number of licensed centres, including mainstream services enrolling large numbers of Pacific Islands children.

e) The Ministry has purchase agreements with PIECCA and Wellington College of Education for the implementation of the Samoan Curriculum in Aoga Amata (Samoan early childhood centres). This curriculum incorporates the principles and goals of Te Whāriki, the early childhood curriculum.

f) The Ministry has a purchase agreement with Anau Ako Pasifika for the delivery of home-based early childhood and parent support programmes as well as for developing appropriate learning resources for use in Pacific homes.

g) The Government purchases services from the ECDU, through a Document of Accountability. These include information and advisory services, parent development services, and the management of contracts. The ECDU also manages the grants for developing PILGs, provides licensing support for centres wishing to become licensed and chartered, and helps parents within unlicensed groups to improve their children's education. It also manages the Parents as First Teachers programme (PAFT), which includes contracts involving the education of Pacific parents.

h) The Ministry is developing supporting documents for the Desirable Objectives and Practices and for Te Wh riki which will also assist Pacific centres.

By April 1998, 40 centres have been licensed and a further 12 are expected to be licensed by the end of the year.

\section{Primary and Secondary Education}

The plan's goal for primary and secondary education is:

To support and carry out initiatives that will raise the achievement levels of Pacific students in the essential learning areas.
Context

In 1997, seven percent of the students enrolled at primary and secondary school were of Pacific origin. Growth in the number of Pacific enrolments has matched that of students from other ethnic groups, and the proportion of Pacific students in both primary and secondary education has grown only slightly since 1992. The proportion of Pacific students in primary education is slightly higher than in secondary education because of the youthful nature of the Pacific population. Most Pacific students are enrolled in the Auckland region (69 percent), followed by the Wellington region (15 percent). These figures correspond with the overall distribution of the Pacific population (Ministry of Education, 1997).

Associated with this regional trend is the tendency for a large proportion of Pacific students to be concentrated in a small number of schools. Statistics show that 20 percent of Pacific students are enrolled in less than 1 percent of schools ( 26 schools), and 50 percent are enrolled in less than 4 percent of schools (104 schools). In addition, in 3 percent of schools, more than half the roll are students of Pacific origin, whereas 44 percent of schools have no Pacific students. This concentration of Pacific students in a small number of schools allows for easy targeting of programmes aimed at improving educational outcomes. ${ }^{6}$

Another feature of the Pacific enrolments is their overrepresentation in integrated schools and their under-representation in private schools. Pacific students are almost twice as likely as other students to be enrolled at an integrated school. This trend has remained stable since data were first collected in 1989. The religious focus of many integrated schools may be a critical factor that results in higher Pacific enrolments.

The proportion of Pacific students staying on at school beyond the age at which attendance is compulsory is very similar to that of non-Pacific students. Pacific females are more likely to stay on at ages 16 and 17 than Pacific males, but more males than females remain to age 18. At age 18, the proportion of Pacific students staying on is slightly higher than those from other ethnic groups, possibly reflecting slower progress of Pacific students through the senior school compared with students from other ethnic groups.

Senior school examination performance is a commonly used indicator of educational achievement. In all national examinations, the performance of Pacific students is considerably lower than that of other students. It is of great concern that at the lowest level of formal 
attainment, School Certificate, only a third (33 percent) of papers sat by Pacific students result in A, B, or C grades. This is just over half the proportion for other students (64 percent). This pattern is repeated in Sixth Form Certificate and University Bursary and Scholarship examinations. Although Pacific students remain at school through to the sixth form in about the same numbers as other students, fewer Pacific students sit examinations beyond the School Certificate level and consequently, Pacific students leave school with fewer qualifications. These patterns were reported in 1995, and the situation in 1997 had changed little (Ministry of Education, 1995; Ministry of Education, 1997). The lower participation in senior school examinations may limit the options of some students in further education and in the labour market.

\section{Progress}

While schools are responsible for meeting the needs of all their students, the Ministry has developed other initiatives to raise the achievement levels of Pacific students in the essential learning areas. These initiatives include such areas as total schoolingimprovement, school management and governance, Pacific teacher development, and resources for teaching. Many projects are delivered within schools while others involve parents and communities. Some projects are implemented specifically to support Pacific students while others, such as some School Support Projects, are implemented in schools with large proportions of Pacific students. These initiatives provide extra assistance to schools to enable them to provide a better education for Pacific students. The following projects are currently being implemented.

a) Taiala mo le Gagana Samoa i Niu Sila/Samoan in the New Zealand Curriculum. The curriculum is available to students wishing to learn the Samoan language, and professional development programmes are available to teachers of the Samoan language in primary and secondary schools. The professional development programme in 1997 provided support mainly to a'oga amata (Samoan early childhood centres), and included some schools. This year, the programme will focus on primary and secondary schools.

b) The Pacific Islands School Parent Community Liaison project aims to improve the links between schools, Pacific parents, and their communities. Six clusters of schools (38 schools) are working on various initiatives, ranging from groups producing resources for parents and communities through to community fono and student support. Teacher development is part of all projects, and an independent evaluation of the project has just been completed.

c) During terms three and four of 1997, a Pacific Islands Teacher Professional Development programme was established. This programme will continue for the next 18 months. Pacific teachers are being given support in curriculum as well as in career development, last year focussing on senior management development.

d) A Pacific Board of Trustees Training programme started in 1997 and will continue in 1998. Areas targeted include Auckland and Wellington. This programme is to assist in improving Pacific members' participation in school governance.

e) Developing resources for teaching Pacific languages in schools is underway, and these will be published later in 1998. Pacific writers have written sections in different languages, and collated examples of good classroom practice to share with other educators.

f) The Ministry has continued to disseminate information on the Collaborative Learning Programme following its successful implementation at secondary level. The programme focuses on improving student performance through the united efforts of teachers, students, parents, Pacific tertiary students, board of trustees members, and the wider Pacific community. Tertiary students are involved as facilitators in classrooms, modelling desirable student behaviour, such as questioning and being prompt. The school liaises with facilitators, parents, students, other teachers, and government agencies. A parent support programme is offered as part of the project.

g) School Support Projects

The Achievement in Multicultural High Schools (AIMHI) project involves eight secondary schools with the highest proportion of Pacific and Maori students. These schools are Hillary College, McAuley High School, Mangere College, Southern Cross Senior and Middle School (formally Nga Tapuwae College), Otahuhu College, Tamaki College, Tangaroa College, and Porirua College. The project aims to improve the students' and schools' performance, and the focus during 1996 and 1997 was to gather baseline data on: student achievement; management performance; school/community relationships; and the impact of contextual issues such as health and 
welfare on student achievement. Strategic planning on information technology and finance are also underway in all schools. A review of national and international research on Pacific peoples' learning styles also commenced in 1996.

In 1997, the research report Towards Making Achieving Cool was released, providing baseline data on all eight secondary schools. During 1998, the project will continue under the management of the AIMHI Forum. The Forum will contract with the Ministry of Education to implement agreed projects within individual schools to improve student and school performance.

Strengthening Education in Mangere and Otara involves 45 schools in the Mangere and Otara areas. A much greater proportion of students in Mangere and Otara identify as Pacific than in any other similar cluster of schools in New Zealand: 58.4 percent of students in primary and 63.7 percent in secondary compared with 4.5 percent primary and 5.4 percent secondary nationally. The project aims to: improve the governance and management capability of schools; further develop more skilled management of resources; develop professional leadership and professional competence of teachers; improve learning outcomes for students; reduce the risk for students of external factors impinging on their learning opportunities; improve school/community relationships by lifting the communities' knowledge, understanding and willingness to engage with the school.

A coordinator and a team of community facilitators are now in place and will continue to consult with schools, parents and their communities and identify priorities for implementation.

Other school resources for which Pacific students are eligible include: funding for English for Speakers of Other Languages, Targeted Funding for Educational Achievement, and Truancy Projects - "Improving School Attendance".

\section{Tertiary Education}

As for other levels of education, the aim is to increase participation and achievement by:

1. Supporting, developing and implementing initiatives for helping to increase Pacific students' participation in training and further tertiary education
2. Increasing targeting and participation in various initiatives in which current uptake by Pacific students is low.

It is acknowledged that more work needs to be put into developing this area.

\section{Context}

The proportion of Pacific school leavers going on to further education is smaller than that for other students. Pacific students who move directly from school to further education are often enrolled in training opportunities programmes rather than at institutions offering higher level qualifications. Some 11 percent of Pacific school leavers moved directly from school to a training opportunities programme, compared with 6 percent of school leavers from other ethnic groups. Conversely, university was a much less frequent destination for Pacific school leavers than for those from other ethnic groups, with 8 percent of Pacific school leavers continuing to university compared with 23 percent for other ethnic groups (Ministry of Education, 1995).

The proportion of Pacific school leavers who continue on to further education is 33 percent, compared with 51 percent for other school leavers. The gap between the Pacific students and students from other ethnic groups was most pronounced for Pacific women (Ministry of Education, 1997)

In 1997, Pacific students made up just over 3.5 percent of all students attending colleges of education, polytechnics, or universities. Commercial and business studies, humanities, and education were the most popular fields of study for Pacific students. Pacific students were a little more likely than other students to be enrolled in humanities, education, or social and behavioural sciences, and communication, and a little less likely than other students to be enrolled in general programmes, commercial and business, or agriculture, forestry, and fishing. Aside from these small differences, Pacific students are enrolled in similar fields of study to students from other ethnic groups.

Government financial assistance to students is available through the student allowances and student loans schemes, and the ability of Pacific students to fund their studies relies heavily on government assistance. The uptake of loans and allowances by students enrolled in formal tertiary education programmes is significantly higher for Pacific students (both full- and part-time) than for other students, while the amounts they receive are similar to students from other ethnic groups. As a result the overall level of government support for Pacific students 
is higher than that for students from other ethnic groups, probably because of the lower income of Pacific families in New Zealand. Fortytwo percent of all full-time Pacific students enrolled at universities, polytechnics, or colleges of education received allowances, compared with 40 percent for students from all ethnic groups. Male Pacific students were slightly more likely to receive allowances than female students. These trends have remained the same over the last two years.

Progress

a) The Ministry has continued to fund courses offered by PIERC Education (formally the Pacific Islands Educational Resource Centre, Auckland) to Pacific students in languages, cross-cultural communications, social and community work, business management, introduction to early childhood education, media studies, English for academic studies, English as a second language, sports administration, positive parenting, and study skills. Some of these courses are provided by other tertiary institutions in conjunction with PIERC Education. Other PIERC Education activities include providing educational resources and consultancy services for early childhood, primary, secondary, and tertiary education. Some of these courses are pre-foundation courses for further tertiary education.

b) In 1996, WMERC Inc. and the Multicultural Centre for Learning and Support Services Inc. (MCLaSS) evolved out of the old Wellington Multicultural Educational Resource Centre. WMERC Inc. focused on offering services to Pacific peoples and operated a library service to all users. Its services to Pacific communities included Pacific language courses, cross-cultural awareness, community parent support and counseling, English for employment, translation, and interpreting. However, in 1997 WMERC Inc. ceased to offer courses. Future provision of this type of service is not yet decided.

c) The Pacific Islands Polynesian Education Foundation administers a scholarship fund that provides either student grants or dollar-fordollar subsidies to donations from various tertiary institutions, city councils and the Norman Kirk Foundation.

d) Other agencies continue to offer services to Pacific students including the Education and Training Support Agency, which offers Skill Enhancement, Training Opportunities Programmes, and
Industry Training and Skill Pathways. Many of these initiatives have targets for Pacific student participation. The Careers Service provides information and advisory services on career information and guidance.

\section{Challenges in the Development of Ko e Ako 'a e Kakai Pasifika}

The Pacific Islands plan is a first for the Ministry of Education. Information was gathered from a variety of sources, which in itself was a challenge, because whilst the term "Pacific" is often used generally, people were actually talking about education for people from Samoa, Cook Islands, Tonga, Tokelau, Niue, Fiji, and Tuvalu, to name just some of the Pacific peoples in New Zealand. So when fono were held, a variety of people had to be given the opportunity to participate fully. This meant that different types of fono were held depending on the situation and the size of the Pacific population in the local area and the community's interest or involvement in education. For instance, fono were held with Samoan teachers in one location and with Samoan educators in other locations, while combined Pacific community fono were more appropriate in other places. Fono were also held with individual Pacific communities, for example, with the Niuean community in one location and the Tongan community in another. Some fono were held with specific church communities, while others were with specific sector groups such as early childhood, or with teacher organisations and principals.

Another challenge was the perception held by Pacific communities that they had been researched too often and that they had received little feedback about the outcomes. However, fono were useful starting points for discussion, some groups acknowledging there is little public discussion by Pacific peoples of Pacific education issues. Fono were also useful in encouraging parent discussion, presenting information to communities about the Ministry's work, encouraging participation and discussing education generally. It also provided the Ministry with insights as to how the implementation of various projects in the past has impacted on Pacific communities.

\section{Conclusion}

It is desirable for Pacific education developments to be comprehensive, and the Ministry is constantly looking to make improvements in many areas, some across education sectors. Therefore, it is important that 
there will be continued discussion with Pacific peoples to establish dialogue and agreement on what good education outcomes should be for them.

The plan is a first step towards developing a long-term Pacific education strategy, ensuring that Pacific peoples are able to participate fully in the education system, and acquire a high level of skills and qualifications from that education.

\section{Notes}

1. The Tongan title for the Ministry's plan for Pacific Islands education, is literally translated as The Education/Schooling of/for Peoples Pacific.

2. The term Pacific Islands is a generalist one developed for convenience. People of Pacific Islands descent identify strongly with their island nations of origin, namely Cook Islands, Fiji, Niue, Samoa, Tokelau and Tonga, to name only the largest groups which have had the longest association with New Zealand. Pacific peoples include those born in the islands as well as those born in New Zealand. It includes all those who identify as having Pacific Islands origins. (Ministry of Education, 1996)

3. Throughout this study, the terms Pacific and Pacific Islands will be used synonymously.

4. School Support Project, Achievement in Multicultural High Schools, Schooling in Mangere and Otara.

5. A gathering of Pacific peoples for consultation, meetings or discussions.

6. These figures have remained virtually unchanged between 1995 and 1997.

\section{References}

Hawk, K. \& Hill, J. (1996). Towards making achieving cool: Achievement in multi-cultural high schools (AIMHI). A report prepared for the Ministry of Education by ERDC, Massey University, Albany Campus.

Krishnan, V., Shoeffel, P., \& Warren, J. (1994). The challenge of change: Pacific Island communities in New Zealand 1986-1993. Wellington: New Zealand Institute of Social Research and Development Ltd.

Ministry of Education. (1995). Pacific Islands peoples in New Zealand education: Education trends report. Wellington: Ministry of Education.

Ministry of Education. (1996). Ko e Ako 'a e Kakai Pasifika: Pacific Islands peoples' education in Aotearoa, New Zealand towards the twenty-first century. Wellington: Ministry of Education.
Ministry of Education. (1997). Education statistics 1997. Wellington: Ministry of Education.

Tongati'o, Lesieli (1994) Challenging success: Developing Pacific Islands education in Aotearoa, New Zealand. Report 1. Wellington: Ministry of Education.

\section{The author}

Lesieli Pelesikoti Tongati'o, is Pule Maata Pasefika, Senior Pacific Islands Adviser with the Ministry of Education (4 years), Wellington. She has spent 3 years lecturing at Tonga Teachers' College, 5 years secondary teaching and 9 years teaching at tertiary levels in New Zealand. She has a particular concern for the education of Pacific peoples, both in Pacific home countries and in New Zealand, and has published a variety of papers. She is interested in research into bilingual education.

Lesieli, originally from Tonga, lives with her family in Palmerston North, has three daughters and loves reading and gardening, whenever possible!! She is involved in many community activities, and is currently National Secretary of the New Zealand Council of Tongan Women. 